\title{
Gender And Poverty Among Elderly In Malaysia
}

\author{
Jariah Masud, Ph.D \\ Malaysian Research Institute on Ageing, UPM
}

Zumilah Zainalaludin, Ph. D.

Faculty of Human Eology, UPM.

\begin{abstract}
The purpose of this study is (1) to examine gender differences in sources of income and poverty among elderly in Malaysia; and (2) to identify factors influencing poverty among male and female elderly in Malaysia. Data for this study were obtained from Malaysian Household Income Survey in 2009 conducted by The Department of Statistics Malaysia. A Total of 16,325 elderly involved in the study. Analysis of descriptive, chi-square and logistic regression were used to address the objectives. Results reveals that gender differences were found in sources of income and poverty among elderly. The main sources of income for both elderly men and women were transfer income. However, majority of men also received income from earning while majority women did not received any money. Higher proportion of women compared to men were poor. Women did not have sources of income which can buffer from poverty. Results from logistic regression explained that, elderly men who are younger and not having sources of income (paid employment, earned, property and transfer) were more likelihood being poor compared to their counterpart. Meanwhile, women who are older, living in rural area, homemaker and not having sources of income (paid employment, earned, property and transfer) were more likelihood being poor compared to their counterpart. It can be concluded that sources of income and age are factors that help both men and women elderly out from poverty. This study might become an additional sources for researcher due to limited study on poverty which focus on gender especially in Malaysia.
\end{abstract}

\section{INTRODUCTION}

Poverty reduction have become one of the national agenda around the world (Samat, Elhadary, Hijles, Ghazali, \& Sirat, 2012) especially in developing countries due to an increasing of population aging (Masud, Haron and Gkonyo, 2008). Poverty in developed country such as United State had shown the reduction over the past 50 years. In 1959, United State reported that incidence of poverty among American are over 35\% but it is reduced each year till about $9 \%$ in recent years (DeNavas-Walt, Proctor, \& Smith, 2014). Malaysia are also followed the foot step of developed countries which focus on reducing the poverty. Program to reduced poverty in Malaysia have been devised since 1970s. It has been successfully reduce rate of poverty from 52.4\% in 1970 to 3.8\% in 2009 (Samat, Elhadary, Hijles, Ghazali and Sirat, 2012).

Elderly are known to be the group that vulnerable to entered poverty (Barrinto, Gorman and Heslop, 2003). This is might due to received lower income compared to younger people (Behanova et al., 2015). Precisely, older and widowed women are known to be the poorest among the poor people (Barrintos, Gorman and Heslop, 2003). Elderly women without husband are more vulnerable toward poverty compared with men and women elderly with spouse. Men have tendency received higher income than women due to more involved in paid employment than women (Fulcher, Sutfin, \& Patterson, 2008). On the other hand, majority women tend to do unpaid labor such as taking care of children and family (Beeghley, 2000). Therefore, men will received much higher income from several type of income sources compared to women. Statistics also showed that unemployment rate among women are higher 
than men. Half from the women elderly are reported never involved in labor force (Masud et al., 2006). Hence, majority women have less income and experienced in managing money compared to men. This eventually make women more depending on men in financial aspect (Wingood \& DiClemente, 2000)). Thus, the possibilities for men to entered poverty are lower compared to women. There were many studies in Malaysia focus on poverty (Roslan, 2001); Nair, 2010) but limited studies focus on specifically on elderly and gender. Hence, this study attempts to answer research questions as below:

\section{Research Questions:}

1. What are the sources of income received by older men and women?

2. Is there a gender difference in incidence of poverty among older persons in Malaysia?

3. What are the factors significantly explain poverty among male and female elderly?

Meanwhile, research objectives of this study are stated below:

\section{Research Objectives:}

1. To compare gender differences in sources of income among elderly

2. To examine gender differences in poverty among elderly

3. To determine factors explaining poverty among male and female elderly

\section{Sources of Income}

\section{LITERATURE REVIEW}

Resources are important for elderly to support their late life. Majority of elderly resources are decreasing with age due to decreasing of abilities to earned income. In developed countries such as United State sources of income for elderly are mainly from social security followed by earnings; pensions and retirement savings; assets and lastly government transfers (He, 2012). Precisely, older men obtained more earned income compared to older women in United State $(\mathrm{Wu}, 2012)$. In developing countries, an involvement of elderly in workforce are higher but the employment opportunities and salary are decreasing with age (Barrintos, Gorman and Heslop, 2003). Worse, women have tendency involved in unpaid labor such as taking care their children and family (Beeghley, 2000). It is hard to find a suitable jobs for women as they need to compete with men. Men on the other hand, are easier to get a job due to the strength and capabilities in various sectors.

Gender roles in household may explained the differences of sources and amount of income among men and women. Men are usually entered the paid employment as they are usually a leader (Blackstone, 2003) and have responsibilities in supporting their family. They have tendency received higher and more sources of income (working-related income) than women. There were several sources of income received by elderly in their late life which is earned income (income received from wage, pension, agriculture and business); investment related income (income received from rent, interest, dividend and bonuses) and social income (income received from remittance from children and relatives) (Masud and Haron, 2014). In term of gender, the main sources of income for women are from their family (Ofstedal, Reidy and Knodel, 2003). Contrary, men are received income from various sources of income compared to women. (Ofstedal, Reidy and Knodel, 2003).

Specifically in Malaysia, majority of elderly received income from work-related income (earned income) and transfer (social income) income (Chan Yin-Fah, Paim et al., 2010). Less of elderly obtained their income from investment-related income (Ofstedal, Reidy and Knodel, 2003). However, amount of income received by elderly from social income are lower than working income and investment related income (Sulaiman, Masud, 2012). Although only a small proportion of elderly received income from investment related income, it can provide higher income for them compared to elderly that solely depend on transfer income. Additionally, in 
spite of the fact that working related and transfer income was proved to be the main sources of Malaysian elderly, there were gender differences found on those two sources. More female elderly are reported obtained income from transfer sources of income while more male elderly received income from work related income (Masud, Haron and Gkonyo, 2008). This is might due to less participation of women in payable labor force compared to men (Masud, Haron and Gkonyo, 2008). Therefore, it is terrifying for women elderly to depend solely on transfer income because they need to depend on other people to obtained their daily needs and want. Sources of income are also one of the important factors contribute toward amount of income received by elderly which consequently determine whether they fall into poverty or not.

\section{Poverty in Malaysia}

Poverty among elderly are remains as an important issues throughout the whole world. The incidence of poverty are occurred depend on how the economic, social and political systems organize (Ali \& Aziz, 2014). The poverty among elderly could affect their abilities to access the markets, basic services and social networks (Barrintos, Gorman \& Heslop). The household are categorized as poor by looking at poverty line income of their country. Each country have their own poverty line income based on the abilities to meet the minimum amount of food and nonfood consumption required for each household (Mohd, 2014). The poverty level in Malaysia for 1970 are recorded as high as $49.3 \%$ but it further decreasing to $1.7 \%$ in 2012 (EPU, 2013). The definition of poverty are broad. It can be defined as simple as an insufficiency of financial resources to fulfill needs (Noble, Smith et al., 2001) toward deprivation of wellbeing (Ali and Azizi, 2014). Based on previous studies, there were two approaches are found in defining poverty which is monetary and capabilities. For the monetary approaches, poverty are determine by financial aspects which is poverty line (Samat, Elhadar et al., 2012). Meanwhile, for capabilities approaches, poverty are not only defined by monetary aspects (Sen, 1999) but also access to public services (Zin, 2007).

Elderly are known to be the most vulnerable group to enter the poverty (Barrintos, Gorman and Heslop, 2003). Older people are known to be poor due to received lower income compared to younger people (Behanova, Katreniakova et al., 2015). Precisely among elderly, older and widowed women are known to be the poorest among poor people (Barrintos, Gorman and Heslop, 2003). It is explained that older women who are stay alone are more vulnerable toward poverty compared to other group of people (Barrintos, Gorman and Heslop, 2003). Older women have tendency involved with poverty might due to less involvement on labor force. Previous studies reveals that less than $50 \%$ of women entered the work force (Masud, Haron \& Gikonyo, 2008). Consequently, women tends to obtained less amount of income compared to men. Thus, they need to depend on other sources of income such as social income which they received from their husband and children to support themselves. Additionally, widowed women are mostly entered the poverty due to not having spouse which could help them in term of financial aspects. However, parallel with involvement of women in higher learning institutions, more women have more abilities to compete with men in work force. It is found that, female labour force have grows from 45.7 per cent in 2005 to 46.4 per cent in 2011 (Malaysia Statistics on Women, Family and Community, 2012). Thus, incidence of poverty among women are expected to decline over time.

\section{Theory}

\section{Gender Role}

There were plenty theory focus on gender by the past researchers in explaining the role of gender. By reviewing these theories, it can be concluded that gender theory could be divided into two section which is biological and nurture theory (Lippa, 2005). The biological theory explained that men and women are different due to their hormone and genetics (Lippa, 2005). 
Their hormone and genetics developed men and women physically and emotionally different since born. Meanwhile nurture theory that explained men and women different due to rearing, social roles, gender belief and social settings (Lippa, 2005). It developed men and women attitude and behavior by learning from society.

Gender role are based on the different expectations that individuals, groups and societies have on individuals based on their sex and based on society values and beliefs about gender. Gender roles are the products of the interactions between individuals and their environments, and they give individuals cues about what sort of behavior is believed to be appropriate for what sex (Blackstone, 2003). The term of gender and sex are different. Sex is biological concept which determined the main sex characteristics while gender refers to femininity and masculinity hold by people with different sexes (Robinson, Riley et al., 2001). Gender is a concept that human developed socially through interaction with other people and environment but also depend heavily in biological differences between male and female.

Gender roles are defined as roles that men and women should hold based on their sexes. According to (Bem \& Allen, 1974) an individual can be categorize into one of the four category of gender roles which is masculine, feminine, androgynous or undifferentiated. A person with androgynous trait defined as a person with high degree of both masculine (instrumental) and feminine (expressive) traits. On the other hand, an individual with undifferentiated traits is a person with low both masculine (instrumental) and feminine (expressive) traits. Women are known to have feminine behavior while men hold the masculine behavior. Women are normally nurture her family by taking care their family and children rather than working in labor force. Men on the other hand, are traditionally roles to be leaders (Blackstone, 2003). They need to be the head of their household which need to support and making decision for their family. It is important for them to provide financial for the family by entered the labor force. Therefore, men have more exposure in financial activities than women.

\section{METHODOLOGY}

The data obtained from Household Income Survey conducted by Malaysia Government in 2009. A total of 16325 older person involved in the study. Four sources of income which is paid employment (income obtained from formal working sector such as wage), earned (income from businesses, agriculture and EPF), Property (investment related income) and transfer (social income which received from children's remittance and welfare assistance) were used in the analyses. Meanwhile, Malaysia poverty line for 2009 are used to define poverty status of the elderly. Respondents are considered as poor if their income are less than the poverty line. A chi-square and logistic regression analyses was conducted. Chi-square analysis was used to study the differences in incidence of poverty. Logistic regression was conducted to examine factors contribute toward poverty. Independent variables for logistic regression include socioeconomic background of the respondents namely; Gender (male or female), age (60 to 69 years old or above 70 years old), marital status (married or not married), strata (urban or rural), household head (yes or no), type of works (formal, own account or homemaker), work status (working, never work or retired) and sources of income such as paid employment (yes or no), earned (yes and no), property (yes and no) and transfer income (yes or no). For ease of interpretation for independent variables, all odds ratio with negative beta (B) will be inversed by using formula of 1 divide by odds ratio. 
FINDINGS

Descriptive results on Socio-demographic Background of Respondents

\begin{tabular}{|c|c|c|c|c|c|c|}
\hline \multirow{2}{*}{$\begin{array}{l}\text { Socio- } \\
\text { demographic }\end{array}$} & \multirow{2}{*}{$\mathrm{n}^{\text {Male }}$} & \multicolumn{2}{|c|}{ Female } & \multicolumn{2}{|c|}{ Total } & \multirow[b]{2}{*}{$\% /$ Mean } \\
\hline & & \%/Mean & $\mathrm{n}$ & $\% /$ Mean & $\mathrm{n}$ & \\
\hline \multicolumn{7}{|l|}{ Gender } \\
\hline Male & - & - & - & - & 7821 & 47.9 \\
\hline Female & - & - & - & - & 8504 & 52.1 \\
\hline \multicolumn{7}{|l|}{ Age } \\
\hline $60-69$ & 4943 & 63.2 & 5041 & 59.3 & 9984 & 61.2 \\
\hline$>69$ & 2878 & 36.8 & 3463 & 40.7 & 6341 & 38.8 \\
\hline \multicolumn{7}{|l|}{ Marital Status } \\
\hline Married & 6591 & 84.3 & 4040 & 47.5 & 10631 & 65.1 \\
\hline Not married & 1230 & 15.7 & 4464 & 52.5 & 5694 & 34.9 \\
\hline \multicolumn{7}{|l|}{ Strata } \\
\hline Urban & 3889 & 49.7 & 4271 & 50.2 & 8160 & 50.0 \\
\hline Rural & 3932 & 50.3 & 4233 & 49.8 & 8165 & 50.0 \\
\hline \multicolumn{7}{|l|}{ Household head } \\
\hline Yes & 6042 & 77.3 & 1852 & 21.8 & 7894 & 48.4 \\
\hline No & 1779 & 22.7 & 6652 & 78.2 & 8431 & 51.6 \\
\hline \multicolumn{7}{|l|}{ Type of Work } \\
\hline Formal & 4961 & 63.4 & 2793 & 32.8 & 7754 & 47.5 \\
\hline own Account & 2196 & 28.1 & 518 & 6.1 & 2714 & 16.6 \\
\hline Homemaker & 664 & 8.5 & 5193 & 61.1 & 5857 & 35.9 \\
\hline \multicolumn{7}{|l|}{ Work Status } \\
\hline Working & 3396 & 43.4 & 906 & 10.7 & 4302 & 26.4 \\
\hline Never Work & 647 & 8.3 & 5075 & 59.7 & 5722 & 35.1 \\
\hline Retired & 3778 & 48.3 & 2523 & 29.7 & 6301 & 38.6 \\
\hline Annual Income & 7821 & 15918.27 & 8504 & 3769.51 & 16325 & 9589.75 \\
\hline
\end{tabular}

Table 1: Socio-demographic Background of Respondent

Table 1 showed socio-demographic background of respondents involved in this study. Number of female respondents (52.1\%) was slightly higher than male (47.9\%) respondents in this study. More than half from total male $(63.2 \%)$ and female $(59.3 \%)$ respondents age 60 to 69 years old while the rest age 70 years old and above. Male respondents are mostly married (84.3\%) contrast with female respondents. Majority of female respondents are not married $(52.5 \%)$. Additionally, majority of male respondents living in rural area $(50.3 \%)$ while female respondents living in urban area (50.2\%). In term of household head, most of male respondents is a household head $(77.3 \%)$ while female are not $(21.8 \%)$. Consistently, men are known traditionally as a leader (Blackstone, 2003). They have responsibilities to support their families financially and making decision. Male respondents are mostly working in formal sectors (63.4\%) while female respondents are homemaker (61.1\%). In term of work status, majority of male are retired (48.3\%) and female are never work (59.7\%). Although male respondents are not working anymore, they still could receive pension in their late life compared to female respondents due to their involvement in labor force when they were young. Thus, male respondents would generate higher income than female respondents. Level of income for male respondents (RM15918.27) was found much higher compared to female respondents (RM3769.51). In summary, majority of male respondents are age between 60 to 69 years old, married, living in rural area, household head, working in formal sectors, already retired and obtained high annual income which is RM15918.27. Meanwhile, majority of female respondents are age between 60 to 69 years old, not married, living in urban area, not a 
household head, homemaker and never work for their entire life and having low annual income which is RM3769.51.

\section{Gender Differences in sources of income among elderly}

\begin{tabular}{|c|c|c|c|}
\hline \multirow{2}{*}{ Source of income } & Male & Female & \multirow{2}{*}{ Chi-square } \\
\hline & $\mathrm{n}(\%)$ & $\mathrm{n}(\%)$ & \\
\hline Paid Employment & $1105(14.1)$ & $256(3.0)$ & $\chi^{2}=659.034 \quad \mathrm{df}=1 \quad$ Sig- $\mathrm{p}=.000$ \\
\hline Earned & $5997(76.7)$ & $2081(24.5)$ & $\chi^{2}=4442.239 \quad d f=1 \quad$ Sig $-p=.000$ \\
\hline Property & $1673(21.4)$ & $548(6.4)$ & $\chi^{2}=774.394 \quad d f=1 \quad$ Sig $-p=.000$ \\
\hline Transfer & $6092(77.9)$ & $2807(33)$ & $\chi^{2}=3310.109 \quad d f=1 \quad$ Sig- $p=.000$ \\
\hline
\end{tabular}

\section{Table 2: Sources of income received by respondents}

Table 2 showed results from chi-square analysis on sources of income received by male and female respondents. Finding reveal that there were gender differences found in all four sources of income which is paid employment income, earned income, investment related income and transfer income. Findings reveal that both male and female respondents mostly received their income from transfer income followed by earned income, property income and lastly paid employment. There were several main result can be explained from the table. The main key findings is main sources of income for both male and female respondents is transfer income. In line with previous study by Masud, Haron and Gikonyo (2008) the main sources of income for elderly is from their children. Secondly, more male respondents received income from paid employment and earned income than female respondents. The percentages of women elderly received work related income are lower than men elderly (Sobieszczyk et al., 2002) due to majority of them not entered work force even when they were younger. Thirdly, more male respondents are reported received incomed from property income compared to female respondents. Men exposed to the investment opportunity due to involvement in work force. Lastly, the results reveal that majority of female respondents don't have income sources. Thus, they need to depend on other people to obtained their need and wants. 


\section{Gender differences in poverty among elderly}

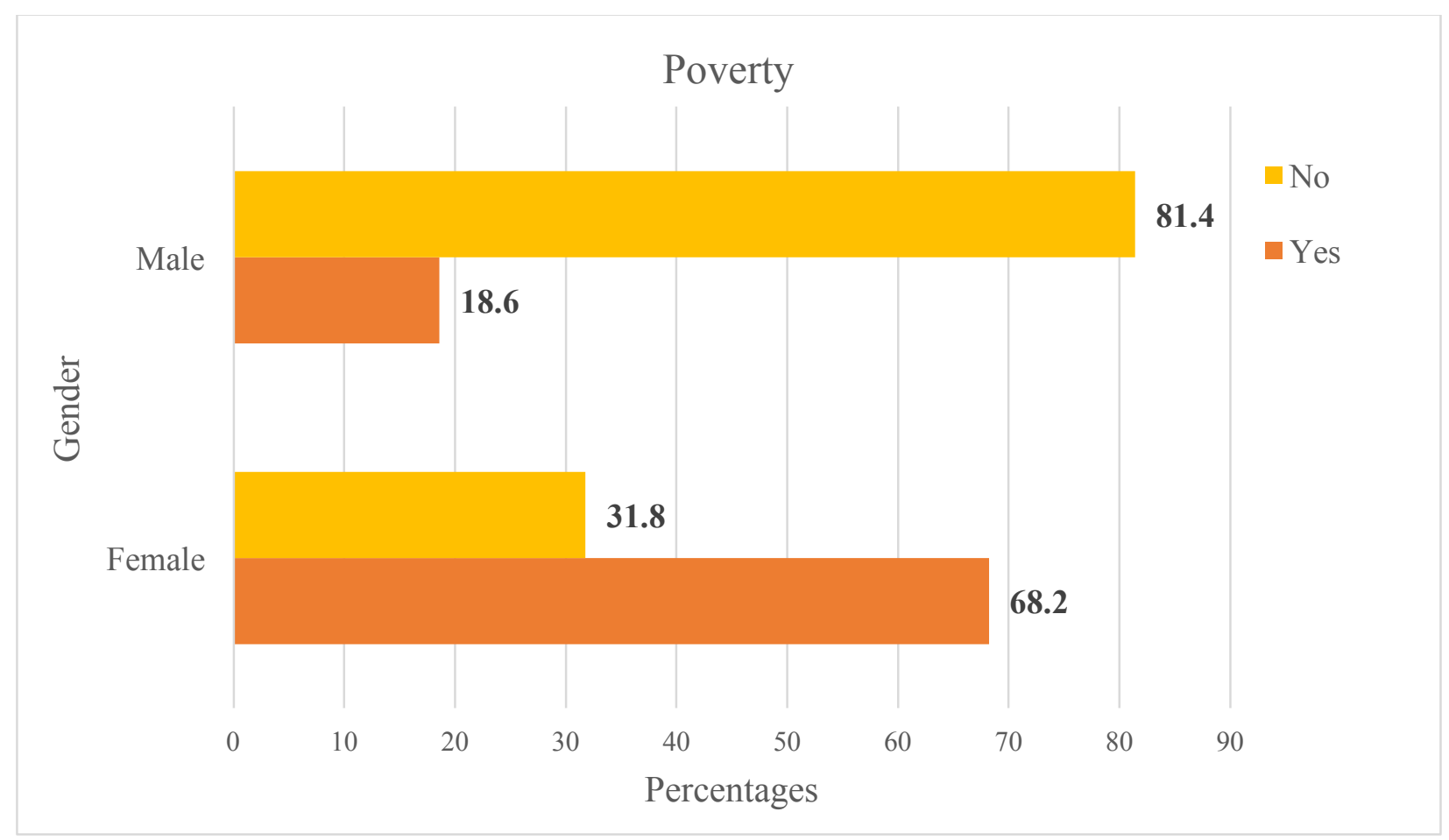

$\chi^{2}=4054.22, d f=1, \operatorname{Sig}-p=.000$

Figure 1 : Gender differences on incidence of poverty

Figure 1 showed results from chi-square analysis for incidence of poverty by respondents. Gender differences was found in incidence of poverty among respondents. It is explained that incidence of poverty between male and female respondents are differ. In comparing between genders, there is a huge gap between male and female that fall into poverty. Almost two third from total female respondents (68.2\%) are poor compared to male respondents $(18.6 \%)$. The results explained that female respondents are mostly poor compared to male respondents. Similarly previous study also supported the result by stated that more women are poor compared to men due to the unstable income (Price, 2008). Unstable income experience by them could consequently prevent them from obtained their needs and wants. 


\section{Factors explaining poverty among male and female elderly}

\begin{tabular}{|c|c|c|c|c|c|c|}
\hline \multirow[t]{2}{*}{ Economic Deprivation } & \multicolumn{3}{|l|}{ Male } & \multicolumn{3}{|l|}{ Female } \\
\hline & B & SE B & $\begin{array}{l}\text { Odds } \\
\text { Ratio }\end{array}$ & B & SE B & $\begin{array}{l}\text { Odds } \\
\text { Ratio }\end{array}$ \\
\hline Age (Ref: 60-69): >69 & $-.219 * * *$ & .203 & .804 & $.387^{*}$ & .147 & 1.472 \\
\hline Strata (Ref: Rural): Urban & -.258 & .230 & .772 & $-.461^{* *}$ & .137 & .631 \\
\hline Marital Status (Other): Married & -.282 & .220 & .755 & -.111 & .152 & .895 \\
\hline Household Head (Ref: No) Yes & -1.747 & .273 & .174 & $1.230^{* * *}$ & .293 & .292 \\
\hline $\begin{array}{l}\text { Work Status (Ref: Working) } \\
\text { - } \quad \text { Never Work } \\
\text { - } \quad \text { Retired } \\
\end{array}$ & $\begin{array}{l}.917 \\
1.962 \\
\end{array}$ & $\begin{array}{l}1.043 \\
1.081 \\
\end{array}$ & $\begin{array}{l}2.501 \\
7.116 \\
\end{array}$ & $\begin{array}{l}-.731 \\
1.354 \\
\end{array}$ & $\begin{array}{l}.823 \\
1.102 \\
\end{array}$ & $\begin{array}{l}.481 \\
3.871 \\
\end{array}$ \\
\hline $\begin{array}{c}\text { Type of Work (Ref: Formal) } \\
\qquad \quad \text { Own Account } \\
\bullet \quad \text { Homemaker } \\
\end{array}$ & $\begin{array}{l}.665 \\
1.464\end{array}$ & $\begin{array}{l}1.104 \\
1.266\end{array}$ & $\begin{array}{l}1.945 \\
4.322 \\
\end{array}$ & $\begin{array}{l}.749 \\
2.854^{* *}\end{array}$ & $\begin{array}{l}1.148 \\
.893 \\
\end{array}$ & $\begin{array}{l}2.114 \\
17.355 \\
\end{array}$ \\
\hline Paid (Ref : No): Yes & $-3.553^{*}$ & 1.177 & .029 & $-3.134^{* *}$ & 1.125 & .044 \\
\hline Earned (Ref: No): Yes & $-3.252^{* * *}$ & .317 & .039 & $-2.852^{* * *}$ & .330 & .058 \\
\hline Property (Ref: No): Yes & $-2.354^{* * *}$ & .508 & .095 & $-1.851^{* * *}$ & .309 & .157 \\
\hline Transfer (Ref: No): Yes & $-4.375^{* * *}$ & .216 & .013 & $-5.240 * * *$ & .159 & .005 \\
\hline$\chi^{2}$ & \multicolumn{3}{|l|}{664.2416} & \multicolumn{3}{|l|}{8932.691} \\
\hline df & \multicolumn{3}{|l|}{12} & \multicolumn{3}{|l|}{12} \\
\hline Cox \& Snell R ${ }^{2}$ & \multicolumn{3}{|l|}{.572} & \multicolumn{3}{|l|}{.650} \\
\hline Nagelkerke $\mathbf{R}^{2}$ & \multicolumn{3}{|l|}{.927} & \multicolumn{3}{|l|}{.911} \\
\hline
\end{tabular}

Table 3: Factors influencing economic deprivation among male and female elderly

Results on Table 3 showed the factors that influencing poverty of male and female elderly. According to the table, full model containing all predictors was statistically significant for male $(\chi 2(12, \mathrm{~N}=7821)=664.2416, p<.001)$ and female $(\chi 2(12, \mathrm{~N}=8504)=8932.691, p<.001)$. It is explained that the model are able to compare between respondents who are poor and notpoor. The Nagelkerke $\mathrm{R}^{2}$ score for male model was .927 while Cox and Snell $\mathrm{R}^{2}$ score was .572. On the other hand, the Nagelkerke $\mathrm{R}^{2}$ score for female model was .911 while Cox and Snell $\mathrm{R}^{2}$ score was .650. Model for male showed that age, sources of income from paid employment, earned, property and transfer income are significantly influenced the incidence of poverty. In details, male age 60 to 69 years old have 12.44 times more likelihood being poor compared to male respondents' age 70 years old and above. In term of sources of income, male respondents with no paid employment (34.48 time), earned (25.64 time), property (10.53 time) and transfer (76.92 time) income have more likelihood of being poor compared to male respondents with sources of income. The younger the male elderly means that they have more responsibilities to support their families. As stated before, male is a leader for the family and have responsibilities in support their families in term of economic (Blackstone, 2003). Therefore, the possibilities them to fall into poverty are higher compared to older male elderly. Also, various sources of income received by male elderly is important to determine level of income they received which consequently determine whether they are poor or not. On the other hand, the model for female showed that age, strata, household head, homemaker, income from paid employment, earned and property are significantly contribute toward poverty of female respondents. Precisely, female respondent age more than 70 years old have 1.472 time more likelihood of being poor. Same with male respondents, female respondents which received paid employment (22.73 time), earned (17.24 time), property (6.37 time) and transfer (200 time) income have more likelihood of being poor compared to their counterpart. As female respondents getting older the abilities for them to work is getting lower and sources of income received from work related income are lessen. Thus, it is directly affect level of income they received which determines their level of poverty. Female respondents who are 
household head are found have 0.292 times more likelihood being poor. Female elderly usually become the household head if they don't married or dead of husband. Thus they need to support their family financially. Female elderly usually received income lower compared to male elderly (Fulcher, Sutfin and Patterson, 2008). Therefore, the possibilities for them to entered poverty are higher compared to female respondents who are not household head. In term of strata, female respondents living in rural area have 1.5858 times more likelihood being poor compared to female respondents living in urban area. Living in rural area could be the obstacle for female elderly to obtained economic sources. Thus, their abilities to increase their income are lower. Female respondents working as homemaker have 17.355 times more likelihood of being poor. Female elderly working as homemaker are usually not received income by their own. They need to support their life by depending on other people. It can be summarized that age, sources of income and strata could determine whether female respondents fall into poverty or not.

\section{CONCLUSIONS}

This study intended to determine gender differences in sources of income and incidence of poverty; and factors contribute toward poverty of male and female elderly. The findings explained that sources of income and incidence of poverty among men and women elderly are different. Men received money mostly from earned and transfer income while women elderly mostly not received income from any sources. Thus, men are more stable financially compared to women. Women on the other hand need to depend on other people to support their daily life. Consistently, result from poverty reveals that majority of women elderly are poor compared to men elderly. This is might due to not having income to obtained their own needs and wants. Age and sources of income are the factors contribute toward poverty among men. While age, strata, household head, homemaker and sources of income were the factors influencing incidence of poverty among women. It showed that age and sources of income are an important factors for both men and women to determine whether the entered the poverty or not. The stability of income of elderly are depend on sources of income they received. Thus, elderly with sources of income other than transfer income could help the elderly to generate stable income for each month and consequently hinder them from poverty.

\section{References}

Barrientos A, Gorman M, Heslop A (2003). Old Age Poverty in Developing Countries: Contributions and Dependence in Later Life. World Development 31(3): 555-570.

Beeghley, 2000 The Structure of Social Stratification in the United States (Third Ed), Boston: Allyn and Bacon.

Behanova M, Katreniakova Z, Nagyova I, Van Ameijden EJ, Van Dijk JP, Reijneveld SA (2015). Elderly from Lower Socioeconomic Groups are more Vulnerable to Mental Health Problems, but Area Deprivation does not Contribute: A Comparison between Slovak and Dutch Cities. The Europe Journal of Public Health: ckv096.

Bem, D. J., \& Allen, A. (1974). On predicting some of the people some of the time: The search for cross-situational consistencies in behavior. Psychological review, 81(6), 506.

Blackstone, A. M. (2003). Gender roles and society. In J. R. Miller, R. M. Lerner \& L. B. Schiamberg (Eds.), Human Ecology: An Encyclopedia of Children, Families, Communities, and Environments. Santa Barbara: ABC-CLIO

DeNavas-Walt, C., Proctor, B., \& Smith, J. (2014). Income, Poverty, and Health Insurance Coverage in the United States: 2012. US Census Bureau. 2013.

Fulcher, M., Sutfin, E. L., \& Patterson, C. J. (2008). Individual Differences in Gender Development: Associations with Parental Sexual Orientation, Attitudes, and Division of Labor. Sex Roles, 58, 330-341. doi: DOI 10.1007/s11199007-9348-4

He, W. (2012). A review of social media security risks and mitigation techniques. Journal of Systems and Information Technology, 14(2), 171-180. 
Lippa, Richard A. 2005 Sexual Orientation and Personality Annual Review of Sex Research Volume 16, 2005 Issue 1, pp. 119-153

Masud J, Haron SA (2014). Income Disparity among Older Malaysians. Research in Applied Economics 6(2): 116

Mohd, S. (2014, June). Poverty Issues among Malaysian Elderly. In Proceeding of the Social Sciences Research ICSSR 2014. (e-ISBN 978-967-11768-7-0).

Nair, S. (2010, September). Moving forward: Its poverty agenda challenges, dilemmas and options for Malaysia. In Proceedings of the Chronic Poverty Research Centre 2010 Conference

Ofstedal, M. B., Reidy, E., \& Knodel, J. (2004). Gender differences in economic support and well-being of older Asians. Journal of Cross-Cultural Gerontology, 19(3), 165-201

Robinson, M. E., Riley, J. L., Myers, C. D., Papas, R. K., Wise, E. A., Waxenberg, L. B., \& Fillingim, R. B. (2001). Gender role expectations of pain: relationship to sex differences in pain. The journal of pain, 2(5), 251-257.

Roslan, A. H. (2001). Income inequality, poverty and development policy in Malaysia. Paper presented at the Internafional seminar on poverty and sustainable sevelopment, Université Montesquieu-Bordeaux IV and UNESCO, Paris, November.

Samat, N., Elhadary, Y. A. E., Hijles, F. M., Ghazali, S., \& Sirat, M. (2012). Poverty and deprivation: using Geographic Information System in evaluating the accessibility of households to food retailers in Penang State, Malaysia. $e$ BANGI, 7(2), 328.

Sobieszczyk, T., Knodel, J. \& Chayovan, N. (2003). Gender and well-being among the elderly: Evidence from Thailand, Ageing and Society 23(6): 701-735.

Sulaiman, H. Masud, I. (2012) Determinants of income security of older persons in Peninsular Malaysia. Pertanika Journal of Social Science and Humanities 20

Wingood, G. M., \& DiClemente, R. J. (2000). Application of the theory of gender and power to examine HIV-related exposures, risk factors, and effective interventions for women. Health education \& behavior, 27(5), 539-565.

Yin-Fah BC, Masud J, Hamid TA, Paim L (2010). Financial Wellbeing of Older Peninsular Malaysians: A Gender Comparison. Asian Social Science 6(3): 58.

Zin, R. M. (2007). Understanding of the Formulation of the revised Poverty Line in Malaysia. Akademika, 70(January), 21-39. 